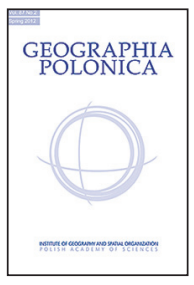

\title{
BERLIN 20 YEARS LATER: DEFINING OR REDEFINING ITS FUNCTIONAL PROFILE? WITH SOME IMPLICATIONS FOR WARSAW
}

\author{
EWA KORCELLI-OLEJNICZAK \\ Institute of Geography and Spatial Organization \\ Polish Academy of Sciences \\ Twarda 51/55, 00-818 Warsaw, Poland \\ E-mail: eko@twarda.pan.pl
}

\begin{abstract}
The paper attempts to define Berlin's functional profile, contrasting it with the expectations and evaluations of the last twenty years. By analyzing employment and investment shares according to sections of the economy (the SIC index) several activities are identified which fulfil the following criteria: they are representative of Berlin, they show progressive development trends, and their role is reflected in the structure of investment outlays. In the analysis, the location co-efficient is used, which allows for the identification of the characteristic features of Berlin's functional profile against the national average structure.

The analysis proves that Berlin has been developing in a relatively ambiguous manner, though its functional specialization is rather stable, in that it has experienced only slight structural changes since the beginning of the 1990s. It is also observed that the position of Berlin in the German urban system is quite stable. In this context, the question is posed as to whether Warsaw's position in the Polish urban system, as expressed in its functional profile, should, when one considers all the parallels and differences, resemble or not the one held by Berlin in Germany.
\end{abstract}

Key words: Berlin, functional profile, location co-efficient, employment structure, representative and progressive functions, Warsaw

\section{INTRODUCTION}

Two decades have elapsed since the momentous events of 1989-1990, which have dramatically altered the political and economic scene in Eastern and Central Europe. This period is sufficiently long to enable some critical reflections to be made concerning recent trends. The contrasting of expectations and predictions pertaining to the evolution of national urban systems and the position of the region's major cities, as expressed at the beginning of that period with those of current developments, often leads to some interesting conclusions. One preliminary assessment is that that the European urban system has not yet reached a state of a long-term equilibrium, as its individual components, as well as its linkage patterns, remain in constant movement.
In the early 1990s, fundamental questions were posed concerning the role of the leading cities in Central and Eastern Europe, while the search for and recognition of their relative positions began to resemble a game of bridge. In particular, with respect to the so-called gateway city functions, it was hypothesized that some of these cities would permanently assume their key roles. The interdependence of Berlin, Vienna, Warsaw, Prague and Budapest was defined in terms of their mutual competition rather than co-operation and functional complementarity (see, for example: Hall 1990, Musil 1995). The positions of these cities were also interpreted in the context of their national urban systems. In this respect it was assumed that due to the strong polycentricity of both German and Polish 
urban systems, the functional structure of Berlin and Warsaw should be characterized by far-reaching analogies (see: Domański 1999). This, however (similar to many other hypotheses formulated in the 1990s), has not been fully confirmed. The functional profiles of the two cities have evolved in response to a number of changing external conditions, and it is difficult to predict when these structures will reach a relatively stable development stage.

In the present paper attempts to address the question of whether Berlin's functional profile tends towards a clear specialization and, at the same time, whether and how this specialization conforms to earlier expectations. The definition of Berlin's functional profile seems to be a relevant issue from the perspective of Warsaw and its search for effective functional specialization. Taking into consideration such indicators as the macroeconomic structure, the level of income and the configuration of the two national urban systems, the research problem of whether Warsaw's position in Poland, as defined by its functional specialization, should correspond to the one held by Berlin in Germany seems to be particularly significant.

\section{BERLIN'S STARTING POSITION IN 1990}

A great deal has been written about Berlin's metropolitan status, its historical stages and changes. In the early decades of the twentieth century, especially during the period of 1920-1933, Berlin developed from an industrial and administrative centre to a glittering, glamorous World City, where modern industry and science were supplemented by the richness of its arts and culture, entertainment and tourism (Zimm 1990). After the Nazis came to power all the inspirational and vivid aspects of the metropolis were dismantled, and Berlin was turned into a centre of war, hatred and destructive propaganda. The years following the war brought the final loss of its metropolitan functions; the de- stroyed city was divided and, after 1949 assigned to two different states founded on alternative social, political and economic systems. Serving in one part as an isolated bridgehead of Western Germany, and in the other as the capital city of the German Democratic Republic, Berlin consequently witnessed its integrity being weakened and eventually destroyed (for a concise diagnosis see: Zimm 1990).

At the beginning of the $1990 \mathrm{~s}$, after the fall of the Iron Curtain and "The Wall", it was an open question as to which direction Berlin would take on its way to (re)establishing) its position. That question was tackled by Knigge (1990) who, in considerable detail, drew the trends of that time, and analyzed the structure of Berlin's economy, and in particular the economy of West Berlin, which to a great extent had been shaped by subventions policy. Due to structural weaknesses, particularly its relatively low efficiency and the loss of key segments of its industrial and service sectors (such as research and product development, finance and marketing) which redounded to the advantage of the large West German cities, the quality of Berlin's labour market had consequently been lowered. As Knigge puts it: "in no other industrial city in Germany (was) the proportion of educated, highly-qualified workers as low as in Berlin, while the share of persons with university degrees employed in the industrial sector (was) for example less than half of that in Munich" (p. 97-98). In a further section of his paper Knigge explained how the spatial economic structure of West Berlin differed from that found in the large urban agglomerations of the Federal Republic of Germany. Such processes as suburbanization, the concentration of decision-making functions in the inner city and the relocation of production and, in general, routine industrial operations to the hinterland, were not taking place. Nonetheless, for its part, the city still possessed some advantages. The educational level of the population was relatively high owing to the city's well developed university system, and research infrastructure was generally available. This applied to, among other 
things, scientific and technical information which, however, was not being effectively utilized.

The main reason for referring here extensively to Knigge's contribution is, however, his in-depth analysis of the development potential of Berlin based on its functional structure. Knigge stressed that the future development path was mostly dependent on political decisions concerning the function of the capital city. This has proved to be a wholly correct, even if it was a somewhat obvious assumption. At the same time, he focused on two areas that seemed not to be directly linked with political solutions. Firstly, as Knigge presumed, while overcoming its isolated situation, Berlin would follow the development path of other large urban agglomerations. Secondly, he anticipated an enormous increase of external demand that would arise after the borders were opened, and from which Berlin would be able to profit to a considerable degree. This would lead to far-reaching consequences for the evolution of Berlin's functional profile, which are described below.

(a) There would be a change of locational patterns concerning most branches of manufacturing, as external demand would first of all relate to technically complex industrial products requiring knowledge-based production systems and face-to-face contacts in the process of product marketing and distribution. Since the activities connected with research and product development in such areas cannot function independently from actual production, this would imply the return of some firms' headquarters to Berlin.

(b) Berlin would experience a boom with respect to other specialized producer services, such as software production, technological, engineering and investment consultancy, marketing, and innovative financial services. This would occur as a result of deficits in these fields in Central and Eastern Europe, and, in this area Berlin would play the role of a gateway city. (c) The third prospective field would comprise consumer services, particularly those connected with medical, psychological, and educational activities. This would require an extension of infrastructure, i.e. investments in schools, universities, hospitals.

\section{MID-TERM EVALUATIONS}

The next ten years led to the above expectations being significantly revised. This resulted primarily from an overestimation of the importance of two issues that had been raised in the early 1990s. The first one was related to the consequences of the return of national capital functions to Berlin, which, as it turned out, has not shaken the German settlement structure in the sense of it not having resulted in a fundamental functional redistribution. At the same time, the major cities of Central and Eastern Europe, in particular the capitals, have managed to overcome the structural and functional gaps between themselves and West European cities, to the extent that the existence of an intermediary a vanguard or an intervening centre - is not necessary. Moreover, the assumption according to which there was only enough space for one major gateway city only in this part of Europe, turned out to be a miscalculation.

Evaluations of the state and development potential, as elaborated around the turn of the centuries and at the beginning of the twenty-first century have led to a significant revision of the radical scenarios concerning the position of Berlin in the German urban system. Both the dream of it fulfilling the role of a "global city", and the pessimistic variant of decline, have proved to be unrealistic. One of the evaluations (KorcelliOlejniczak 2004, 2007) was that Berlin had experienced a quicker advancement at the international level, i.e. in the urban system of Central and Eastern Europe than within its national urban system. The position of Berlin vis-à-vis other large German cities, save for its capital city functions, had not changed significantly since 1991. Berlin 
succeeded in profiting from its privileged position of a divided double-city situated astride the boundary between two different political systems by maintaining and enriching its imposing cultural potential, and, by becoming a centre of culture, as well as offculture. Hence in the category of 'production and reproduction' functions (Bourne 1997) Berlin was considered to gain global, or at least transnational importance in its cultural functions, and, a national importance with respect to science and education.

Furthermore, Kujath (2005) emphasised that R\&D is a major component of the development potential of Berlin. Notwithstanding a deep decline in manufacturing, a number of new service sector activities were identified in Berlin, based on the growing importance of knowledge as a production factor. Kujath found out that knowledge-intensive business activities were growing faster than all other branches of the economy, when measured by both employment number and gross added value. While characterizing Berlin's functional specialization, Kujath distinguished the following activities as the core of the city's economic potential: transportation technologies, medical and biological technologies, R\&D intensive industries, software development, cultural production and producer services in general. As he wrote, "Berlin (was) among the 15 leading urban regions for scientific research and technological achievements in Europe, and a leading European region for cultural production" (Kujath 2005: 121).

\section{BERLIN'S FUNCTIONAL PROFILE ACCORDING TO EMPLOYMENT AND INVESTMENT TRENDS}

It may now be interesting to confront the above evaluations and expectations with some recent research, as well as with the results of an analysis based on employment and investment statistics. The framework of the analysis rests on the assumption that an attempt at defining or redefining a city's functional profile requires the identification of those sectors which are, on the one hand, representative of the city, and, on the other, show a progressive development trend. How representative and progressive the activities are constitute two preconditions for defining a given activity as a component of the city's regional specialization; or, to put it differently, its functional profile.

The attempt at identifying these sectors which fulfil both criteria has been carried out in the course of a rather simple analysis:

1. For all sections of the SIC index the share of employment in Berlin and Germany were compared. This resulted in the calculation of the so-called location coefficient, which is a quotient of the share of employment in a particular section in Berlin and the same share in Germany multiplied by 100 .

$$
\mathrm{LCn}=\mathrm{SBn} \div \mathrm{SGn} \times 100 ;
$$

where $\mathrm{S}$ stands for share, $\mathrm{G}$ for Germany, $\mathrm{B}$ for Berlin, and $\mathrm{n}$ is the individual section.

2. The same procedure was applied for five selected years, showing individual stages of development: 1991, 1995, 2000, 2005 and 2008, which allowed for a dynamic evaluation of changes and trends since 1991

3. The sections were identified which, in the final year, had high values of the location coefficient. This again was compared with the shares for Berlin and Germany in order to eliminate the sections in which the numbers were low.

4. The development trends in the chosen sections were compared and contrasted with similar trends concerning changes in the investment profile of Berlin.

The calculation produced the following results (see Table 1$)^{1}$ :

1 The Author uses the SIC index 2003, as the data obtained from the Statistical Office of BerlinBrandenburg has been presented according to these headings. The paper contains an appendix which presents the description of the employer classification symbols for both 2003 and 2007. 
Table. 1 Location coefficient trends for Berlin (SIC index 2003)

\begin{tabular}{lrrrrr}
\hline Activity/ Year & 1991 & 1995 & 2000 & 2005 & 2008 \\
\hline A/B & 28 & 42 & 38 & 30 & 25 \\
C-E & 70 & 58 & 52 & 47 & 46 \\
D & 65 & 55 & 50 & 47 & 43 \\
E & 158 & 154 & 162 & 125 & 150 \\
F & 161 & 107 & 92 & 82 & 80 \\
G-P & 116 & 118 & 117 & 121 & 120 \\
G & 100 & 88 & 80 & 81 & 82 \\
H & 120 & 113 & 125 & 142 & 143 \\
I & 140 & 126 & 103 & 105 & 103 \\
J-K & 126 & 141 & 134 & 131 & 133 \\
J & 90 & 100 & 93 & 83 & 82 \\
K & 149 & 159 & 146 & 145 & 143 \\
L-P & 121 & 123 & 132 & 132 & 131 \\
L & 120 & 133 & 151 & 154 & 147 \\
M & 122 & 125 & 132 & 128 & 132 \\
N & 123 & 118 & 120 & 116 & 116 \\
O & 158 & 151 & 156 & 172 & 166 \\
P & 36 & 41 & 50 & 68 & 156 \\
\hline Source & Auth & & &
\end{tabular}

Source: Author's own elaboration according to the SIC index. Data obtained from Amt für Statistik Berlin-Brandenburg.

The location coefficient (LC) is a measure which shows the functional position of a city against the national average, and can therefore be interpreted as an expression of the degree of specialization in the city. In this case, it is assumed that values considerably above 100 are treated as significant.

In order to define Berlin's specialization profile, the first step was to identify those activities which had the highest LC in the final year (2008) of the analysis. The calculation shows that sections G-P, standing for service activities, are slightly higher than average for Germany, which again for such a prominent city as Berlin is not very high. The sections which stand out positively in the present analysis are: E (electricity, gas and water supply -LC 150), H (services related to tourism, such as hotels, motels, restaurants, camping fields, student and youth hostels, bars, cafeterias and other gastronomic facilities - LC 143), $\mathrm{K}$ (real estate service, organization and sales, activities of real estate agencies; IT services, such as consulting data bases, science, R\&D activities, investment and management consulting, market research, urban planning, advertisement, other business services and activities) -LC 143), L (public administration and national security, social care, law and jurisdiction activities, activities connected with public order and security LC-147), O (other community, social and personal service activities, including those activities connected with labour unions; business, professional, political, religious and employment organizations; recreation, culture and sports activities; cultural institutions, such as theatres, museums, libraries, archives - LC 166) and P (private households with employed persons LC-156).

It has to be pointed out that the location coefficient does not necessarily express the actual dimension of functional specialization. This is due to the fact that in some cases, the share of employed in a particular section of Berlin is actually low, although still higher when compared with the average for Germany as a whole. In the present analysis this leads to the elimination of section $\mathrm{E}$, were the quotas are as low as: $0.9 \%$ for Berlin, $0.6 \%$ for Germany; and section $\mathrm{P}$, were the share is $1.4 \%$ for Berlin and $0.9 \%$ for Germany. Conversely, there are also sections in which the LC for Berlin is lower than in those listed earlier, but in terms of the share of total employment they have experienced considerable growth since 1991 (sections $\mathrm{M}$ : education and $\mathrm{N}$ : health care and social work). In section $\mathrm{M}$ the employment share has grown by $2.1 \%$; and in section $\mathrm{N}$ by 3.2 percentage points. In both sections the LC lies above 110 . The activities identified via this procedure can be defined as being representative of Berlin. The progressive character of these functions has been investigated by comparing trends, i.e. the changes in values of the location coefficient. Among sections $\mathrm{H}, \mathrm{K}, \mathrm{L}, \mathrm{O}, \mathrm{M}$ and $\mathrm{N}$ fully positive trends were observed in sections $\mathrm{H}$ (tourism) and $\mathrm{M}$ (education), whereas the values for section O (culture, sports, recreation) fluctuated, while nonetheless being maintained at a high level. Section L (public administration) has witnessed only a slight decrease since the year 2000 (the peak in the year 2000 was as high as 151). Similarly, section K (real estate, science, R\&D) has experienced a decrease since 1995, but the differences are small and the coefficient values remain high. This also reflects the situ- 
ation of activities connected with health care and social work $(\mathrm{N})$, where the coefficient has been more or less stable since 1991.

Another indicator which indirectly, but rather precisely describes the evolution of the functional structure are the investment input values in the respective sections of the economy. Therefore, the respective data for Berlin were compared with the average for Germany. The comparison pertained to all sections for which there was available data. In particular, the focus was put on the six sections identified on the basis of the LC analysis as representative and considerably progressive (Table 2).

The comparison shows that with respect to the six identified sections only in those related to education, culture, health and social work do the share of investment inputs in Berlin exceed at most stages the respective share for Germany. The other sections which score highly when compared are those connected with construction, transportation, storage and communication (the media), as well as financial services. For those sections an index analogous to the location coefficient was calculated. The results are presented in Figure 1.

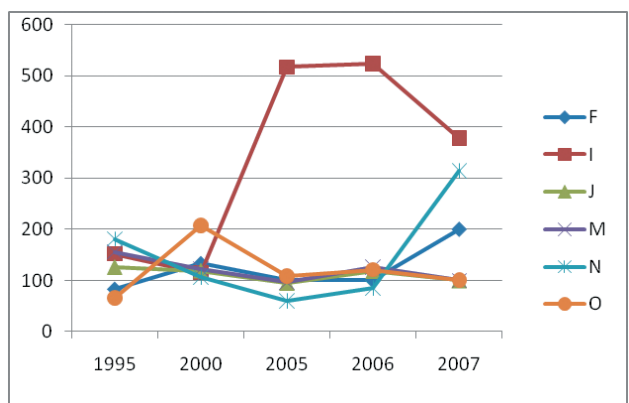

Figure 1. Investment index for Berlin related to sections with positive allocation ratios.

Source: Author's own calculation based on data obtained from Amt für Statistik Berlin-Brandenburg.

As can be observed, the structure of investment outlays does not seem to quite follow the employment structure; moreover, it does not seem to react to, nor have a direct influence on the growth of employment in particular sections. It can, however, be assumed that sections $\mathrm{M}, \mathrm{N}$ and $\mathrm{O}$ are those that show positive indicators both with respect to employment and the investment structure. This could also lead to the conclusion that they constitute by far the most representative, progressive and durable segments of Berlin's economy.

At this point it is useful to contrast the results with the findings presented by Stein (2009) in a recent paper on Berlin's specialization profile. The paper deals with the question as to whether the development potential, as identified for the purpose of urban policy (Enquete-Kommission 2005), could indeed be treated as the city's specialization, and, therefore, would the support and promotion of these fields lead to a general growth of employment and income.

Stein's analysis was based on a comparison of the shares of employed in a number of professions identified according to the German "Classification of Professions" (KldB 1988). The professions were selected in line with the development fields identified by the EnqueteCommission and the Berlin Senate (2005) and pertained to: science, culture, the health sector, as well as communication and transport. Additionally, the author investigated employment in professions connected with functions that are specific to a large city, i.e. managerial positions, jobs in banking and financial services, law, investment and business consulting. At the same time, the paper presents an alternative classification of activities concerning the latter fields, which are defined as 'transaction activities', and introduces another, more functional approach when it comes to interpreting data concerning these professions and activities.

In the course of the analysis the location coefficient was calculated by Stein for 320 professions in the selected fields, with a total of 985000 employed in Berlin in 2007. The comparison shows that there were 103 jobs with an LC above 100, i.e. the share in Berlin was higher than the average for Germany as a whole, which included 36 professions with an LC above 150, and 18 with an LC above 200 . The professions were mainly related to activities connected with culture, science and transportation. The regional specialization was by far the highest for professions linked with cultural activities (LC >218.7). These include artists, musi- 
Table 2. Investment outputs according to the SIC index (2003) in Berlin and in Germany

\begin{tabular}{|c|c|c|c|c|c|c|c|c|c|c|}
\hline & \multicolumn{10}{|c|}{ Investment outputs according to the SIC index (2003) in Berlin and in Germany } \\
\hline & \multicolumn{2}{|c|}{1991} & \multicolumn{2}{|c|}{1995} & \multicolumn{2}{|c|}{2000} & \multicolumn{2}{|c|}{2005} & \multicolumn{2}{|c|}{2007} \\
\hline & Berlin & Germany & Berlin & Germany & Berlin & Germany & Berlin & Germany & Berlin & Germany \\
\hline $\mathrm{A} / \mathrm{B}$ & 0.3 & 0.8 & 0 & & 0 & & & & & 0.7 \\
\hline $\mathrm{C}-\mathrm{E}$ & 6.5 & 9.1 & 8.6 & 7.5 & 5 & 6.3 & 5.1 & 8.1 & 5 & 5.6 \\
\hline $\mathrm{C}$ & & & & & & & & & & \\
\hline $\mathrm{D}$ & & & 3.1 & 3.6 & 0.9 & 3.7 & 1 & 2.6 & 1.1 & 3.4 \\
\hline E & & & & & & & & & & \\
\hline $\mathrm{F}$ & 0.5 & 0.5 & 0.5 & 0.6 & 0.4 & 0.3 & 0.1 & 0.1 & 0.2 & 0.1 \\
\hline G-I & 8.2 & 10.6 & 12.4 & 8.1 & 6.2 & 6.6 & 28.2 & 7.9 & 22 & 7.5 \\
\hline G & & & 4 & 2 & 1.1 & 1.9 & 0.5 & 2 & 1 & 2.1 \\
\hline $\mathrm{H}$ & & & 0.2 & 0.5 & 0.4 & 0.4 & 0.3 & 0.4 & 0.3 & 0.4 \\
\hline I & & & 8.2 & 5.4 & 4.7 & 4.1 & 27.4 & 5.3 & 18.9 & 5 \\
\hline $\mathrm{J}-\mathrm{K}$ & 60.9 & 55.5 & 59.1 & 62.5 & 55.7 & 66 & 43.7 & 64.6 & 44.7 & 63 \\
\hline $\mathrm{J}$ & & & 2.9 & 2.3 & 2.5 & 2.1 & 1.8 & 1.9 & 1.8 & 1.8 \\
\hline K & & & 56.1 & 59.4 & 53.2 & 63 & 41.9 & 61.9 & 42.9 & 63.3 \\
\hline L-P & 20.5 & 23.3 & 19.5 & 22.5 & 32.7 & 14.4 & 22.9 & 21.7 & 29.9 & 21.5 \\
\hline $\mathrm{L}$ & & & 7.5 & 7.9 & 12.8 & 5.5 & 10.8 & 8.3 & 7.1 & 7.9 \\
\hline M & & & 3.9 & 2.5 & 2.8 & 2.3 & 2.4 & 2.5 & 2.6 & 2.6 \\
\hline $\mathrm{N}$ & & & 2.9 & 1.6 & 4.5 & 4.2 & 2.6 & 4.3 & 13.2 & 4.2 \\
\hline $\mathrm{O}$ & & & 5.1 & 7.7 & 12.7 & 6.1 & 7.1 & 6.5 & 7 & 6.9 \\
\hline
\end{tabular}

Source: Author's own elaboration based on data obtained from Amt für Statistik Berlin-Brandenburg.

cians, sketchers, painters, translators, photographs, publishers etc.

The second place is occupied by the so called 'health economy sector'. Although the share of employed in this sector is the highest among the four selected fields, the regional specialization in these activities is not as high as that relating to culture.

The field of science was divided into two areas: research \& development, and human and social sciences as well as teaching. This field occupied the third place among the selected activities. A high location coefficient was found first of all with respect to the second area.

The index for the fourth field, transportation, was not especially high. Among all the jobs in this field, rail transportation was particularly highly represented.

Stein also attempted to analyze the employment structure of Berlin using the category of so-called transaction activities, which are defined as all activities which require highly specialized skills and are based on the coordination of exchange, or transfer between economic actors, either private persons or organizations. The contemporary literature of the subject often describes the functional structure and position of a metropolis on the basis of its performance in transaction activities. In this case, the employment structure was evaluated with respect to these logics. The analysis has shown that the general specialization index for transaction activities was relatively high (LC 156.6); yet some jobs belonging to this category were underrepresented. This mostly related to business and financial services, which provides poor evidence for the limited scope of the city's managerial functions. The professions, among those related to the transaction activities described as Berlin's regional specialization on the basis of the location coefficient were: real estate agents, auctioneers, specialists in publishing, bookselling and marketing, organization of congresses and fairs. The 
plane of interaction of the sectoral and functional evaluation had shown the dominance of activities connected with culture, whereas science had occupied the second place. The most profound example is the position of Berlin with regard to transaction activities in the publishing business. With its 141 specialist journals Berlin is known to occupy the first place among the German metropolitan centres.

\section{FUZZY BUT STABLE SPECIALIZATION}

When contrasting the evidence concerning the earlier development stages with the results of the current analyses it seems obvious that Berlin is developing a regional specialization, i.e. it has actually been developing one since the beginning of the 1990s. Its profile is, however, somewhat fuzzy, meaning that the performance of some functions, although treated as part of the city's potential, does not find reflection in its nationwide position. This may be due to the fact that reaching the German average is already extremely demanding, as there are many urban regions with either clear and narrow, or clear and wide functional specializations throughout the country. An interesting phenomenon is that the values of the location coefficient have not experienced dramatic changes after the transfer of capital city functions to Berlin, and that they have remained in a certain balance since 1991. This proves that Berlin has in a way been assimilated into the overall functional development in Germany, and that it has secured an important position in those fields which were originally identified as having development potential. At the same time, there is no defined single activity, or group of activities which show a tendency to actually dominate the functional profile of Berlin. Moreover, it is characteristic that the functions identified as representative and progressive have maintained relatively stable relations with respect to each other.

The employment trends analysis and the investment outlays statistics have shown that those sectors that are the most representative, progressive, and at the same time sustained in their evolution, are related to such activities as education, health and social work, as well as other community, social and personal service activities: those, connected with labour unions; social, business, professional, political, religious and employment organizations; recreation, culture and sports activities; the functioning of cultural institutions: theatres, museums, libraries, and archives. Additionally, positive trends can also be observed in activities covered by section K, which encompasses science, R\&D and businesses associated with the real estate market. Stein's analysis of Berlin's specialization in transactional activities shows additionally that the city's functional profile also builds upon those sectors which lie on the interface between culture and science and their transfer, i.e., where resources are sold, rented, presented, processed or converted. These concern tourism, exhibitions, publishing, auctioning, the organization of congresses and cultural venues. This also concerns young creative industries, and knowledge-intensive business activities.

Summing up, it seems to be increasingly visible that, although fluctuations within the functional system are present, dissipative structures are present circulating relatively near to an equilibrium position. It would seem that Berlin's regional specialization, and the position of the city in its national urban system, have reached a state of semi-balance, which does not leave much space for dramatic change. The capital-city functions, and the role of being a cultural global-city, backed up by some creative transactional activities, have given Berlin a particularly stable position in Germany, as well as in Europe. This, however, does not imply that there is even a slight tendency towards it becoming more dominant in the national dimension.

\section{BERLIN'S REGIONAL SPECIALIZATION BUILDING AND ITS IMPLICATIONS FOR WARSAW - SOME CONCLUDING REMARKS}

As was suggested at the beginning of the present paper, observing the evolution of Berlin's functional profile can be useful when try- 
ing to answer the question of whether Warsaw should develop a functional specialization, if it still has not clearly developed one, and whether this specialization should in any way react, respond or correspond to Berlin's economic profile. Another question is whether Warsaw's position in Poland should be analogous to that of Berlin in Germany. At the same time, it should be stressed that the functional evolution of the German capital can in no way to be treated as an expression of a growing interdependence between the two cities. Recent analyses show that this is developing to a lesser extent than it had been during the 1990s, and to a considerably smaller degree than had been anticipated. Furthermore, in the light of the recent trends, the issue of Berlin's dominance over the Polish urban system, including Warsaw, seems now to have been closed. Nonetheless, the geographical proximity, the (one-way) connectivity of the Polish economy with its German counterpart, the historical parallels, as well as the policentricity of the Polish and German urban systems, continue to allow for comparison, and a closer look at the development of the other city.

Warsaw's functional profile seems to be less stable than that of the German capital. The city has redefined its development potential on several occasions during the last few decades, focussing either on economic or non-economic functions, the performance of which constitutes its raison'd'étre in both the national and international dimensions (see: Development Strategy for the City of Warsaw 2005). Considering Warsaw's strong and, in many ways, leading position in the Polish urban system, which is confirmed by economic data and urban rankings, with respect to economic and decisionmaking functions in particular (Śleszyński 2007), one can justifiably assume that the city should not strive to achieve a narrowly defined functional specialization. By taking advantage of its internal position, and the high degree of closure of symbolic functions within the boundaries of national urban systems, Warsaw should strengthen its position, and while overcoming its structural weaknesses, develop the optimum functional structure in terms of breadth and flexibility which would lead to a growth of its location coefficients in both economic and noneconomic sectors. To strive for a narrower and strictly defined functional pattern would on the one hand lead to stronger competition within the national urban system, and on the other, weaken Warsaw's chances in the European dimension.

Amore thorough investigation of Warsaw's regional specialization would in all likelihood substantiate the formulated conclusion.

\section{REFERENCES}

Bourne, L. S. (1997), Polarities of structure and change in urban systems: a Canadian example, Geojournal 43.4, Kluwer Academic Publishers, The Netherlands, pp. 339-349.

Development Strategy for the City of Warsaw until 2020 (2005), Urzad Miasta Stołecznego Warszawy [The Municipal Council of the Capital City of Warsaw], Warszawa.

Domański R. (1999), The changing map of Europe. The Trajectory Berlin- PoznańWarsaw, Friedrich Ebert Stiftung, Warszawa.

Enquete-Kommission (2005), Eine Zukunft für Berlin, Abgeordnetenhaus Berlin, Drucksache 15/4000 .

Hall, P. (1990), Europe after 1992, in: Urban Challenges, Statens offentliga utredninger, Stockholm, pp. 179-185.

Süß, W. (Ed.) (1995; 1996), Hauptstadt Berlin, Vol. 1, 2, 3, Verlag Berlin.

KldB (1988), Klassifizierung der Berufe, Systematisches und Alphabetisches Verzeichnis der Berufsbenennungen, Bundesanstalt für Arbeit, Nürnberg.

Knigge, R. (1990), Stärken und Schwächen der Wirtschaftsstandortes Berlin (West), in: Stadtforschung in Ost und West. Perspektiven und Möglichkeiten der Kooperation der großen Zentren in Europa, Beiträge 116, Akademie für Raumforschung und Landesplanung, Hannover, pp. 96-102. 
Korcelli-Olejniczak, E. (2004), Funkcje metropolitalne Warszawy w latach 19902002. Współzależność pozycji w systemie miast Europy Środkowej [Interdependence of ranks in the urban system of Central Europe], Prace Geograficzne 198, Instytut Geografii i Przestrzennego Zagospodarowania (IGiPZ), Warszawa.

Korcelli-Olejniczak, E. (2007), Berlin and Warsaw: in search of a new role in the European urban system, Journal of Housing and the Built Environment, Vol. 22 No. 1, pp. 51-68, Springer Verlag, The Netherlands.

Kujath, H.J. (2005), Restructuring of the Metropolitan Region of Berlin-Brandenburg: Economic Trends and Political Answers, Geographia Polonica, Vol. 78, No. 1, (IGiPZ) PAN, Warszawa.

Musil, J. (1995), The potentials and limits of Prague. Questions In perspective, in Demarie, M.(ed.), Citta capitali dell'Europa centrale: politiche e strategie urbane nel nuovo spazio europeo, pp. 177-213. Fon- dazione Giovanni Agnelli, Torino.

Śleszyński, P. (2007), Gospodarcze funkcje kontrolne w przestrzeni Polski [Economic control functions in Poland's space], Prace Geograficzne 213, Instytut Geografii i Przestrzennego Zagospodarowania (IGiPZ) PAN, Warszawa.

Stein, R. (2009), Besondere und allgemeine metropolitane Spezialisierungen in Berlin : Kultur und Wissenschaft, Koordination und Transaktion, Raumforschung und Raumordnung, No 4/2009, Carl Neumanns Verlag, Akademie für Raumforschung und Landesplanung, Hannover.

Zimm, A. (1990), Die metropolitane Entwicklung Berlins, in: Stadtforschung in Ost und West. Perspektiven und Möglichkeiten der Kooperation der großen Zentren in Europa, Beiträge 116, Akademie für Raumforschung und Landesplanung, Hannover, pp. 13-21. 


\section{APPENDIX}

\begin{tabular}{|c|c|c|c|}
\hline \multicolumn{2}{|c|}{2003 SIC - main classification headings } & \multicolumn{2}{|c|}{2007 SIC - main classification headings } \\
\hline Section & Description & Section & Description \\
\hline A & Agriculture, Hunting and Forestry & A & Agriculture, Forestry and Fishing \\
\hline $\mathrm{B}$ & Fishing & & \\
\hline $\mathrm{C}$ & Mining and quarrying & B & Mining and quarrying \\
\hline $\mathrm{D}$ & Manufacturing & $\mathrm{C}$ & Manufacturing \\
\hline \multirow[t]{2}{*}{$\mathrm{E}$} & Electricity, gas and water supply & $\mathrm{D}$ & $\begin{array}{l}\text { Electricity, gas, steam and air conditioning } \\
\text { supply }\end{array}$ \\
\hline & & $\mathrm{E}$ & $\begin{array}{l}\text { Water supply, sewerage, waste management } \\
\text { and remediation activities }\end{array}$ \\
\hline $\mathrm{F}$ & Construction & $\mathrm{F}$ & Construction \\
\hline G & $\begin{array}{l}\text { Wholesale and retail trade: repair of motor } \\
\text { vehicles, motorcycles and personal and } \\
\text { household goods }\end{array}$ & G & $\begin{array}{l}\text { Wholesale and retail trade; repair of motor } \\
\text { vehicles and motorcycles }\end{array}$ \\
\hline $\mathrm{H}$ & Hotels and restaurants & $\mathrm{I}$ & Accommodation and food service activities \\
\hline \multirow[t]{2}{*}{ I } & Transport, storage and communications & $\mathrm{H}$ & Transportation and storage \\
\hline & & $\mathrm{J}$ & Information and communication \\
\hline $\mathrm{J}$ & Financial intermediation & $\mathrm{K}$ & Financial and insurance activities \\
\hline \multirow[t]{3}{*}{$\mathrm{K}$} & Real estate, renting and business activities & $\mathrm{L}$ & Real estate activities \\
\hline & & M & Professional, scientific and technical activities \\
\hline & & $\mathrm{N}$ & Administrative and support service activities \\
\hline $\mathrm{L}$ & $\begin{array}{l}\text { Public Administration and defence; } \\
\text { compulsory social security }\end{array}$ & $\mathrm{O}$ & $\begin{array}{l}\text { Public administration and defence; } \\
\text { compulsory social security }\end{array}$ \\
\hline M & Education & $\mathrm{P}$ & Education \\
\hline $\mathrm{N}$ & Health and social work & Q & Human health and social work activities \\
\hline \multirow[t]{2}{*}{$\mathrm{O}$} & $\begin{array}{l}\text { Other community, social and personal } \\
\text { services activities }\end{array}$ & $\mathrm{R}$ & Arts, entertainment and recreation \\
\hline & & $\mathrm{S}$ & Other service activities \\
\hline $\mathrm{P}$ & $\begin{array}{l}\text { Activities of private households as employers } \\
\text { and undifferentiated production activities of } \\
\text { private households }\end{array}$ & $\mathrm{T}$ & $\begin{array}{l}\text { Activities of households as employers; } \\
\text { undifferentiated goods- and services- } \\
\text { producing activities of households for own use }\end{array}$ \\
\hline Q & Extraterritorial organizations and bodies & $\mathrm{U}$ & $\begin{array}{l}\text { Activities of extraterritorial organizations and } \\
\text { bodies }\end{array}$ \\
\hline
\end{tabular}

Source: SIC (Standard Industrial Classification) available from $<$ http://www.businessballs. com/industrialclassifications.htm> 
http://rcin.org.pl 